\title{
Edukacja obywatelska dorosłych w Warszawie - w stronę lokalności i aktywności
}

\author{
Citizenship education of adults in Warsaw - towards \\ indigenousness and activity
}

Streszczenie. Poniższy artykuł przedstawia wstępną analizę edukacji obywatelskiej dorosłych przeprowadzonej w oparciu o oficjalne dokumenty, strategie, programy oraz materiały informacyjne m.st. Warszawy, które dotyczą m.in. budżetu partycypacyjnego i domów sąsiedzkich. Z przeprowadzonej analizy wynika, że koncepcja obywatelskiej edukacji dorosłych w Warszawie zakorzeniona jest w nurcie uczenia się w lokalnych społecznościach oraz założeniach aktywnego obywatelstwa. Takie podejście jest naszym zdaniem wykluczające, ponieważ głównymi odbiorcami działań edukacyjnych są już aktywni mieszkańcy. Nie dociera ona za to do grup defaworyzowanych. Analiza ujawniła również instrumentalność samego procesu edukacji, który wykorzystywany jest przede wszystkim do realizacji zmian społecznych.

Słowa klucze: edukacja obywatelska, edukacja dorosłych, polityki miejskie, aktywne obywatelstwo, edukacja wykluczająca

Summary. The article presents an initial analysis of Warsaw's adult civic education based on legal documents, strategies, programs, and information materials concerning participatory budgeting and community centers. Results show that the concept of adult civic education in Warsaw is rooted in local communities' learning traditions and the tenets of active citizenship. In our opinion such an approach is exclusive because its main recipients are already civically active residents, and such educational efforts do not reach disadvantaged groups. Our analysis also proves that the educational process is used as a tool to implement social change.

Key words: civic education, adult education, local policies, active citizenship, exclusive education 


\section{Aktywne obywatelstwo i lokalność we współczesnej edukacji obywatelskiej dorosłych}

Edukacja obywatelska to wszelka „(...) edukacja, szkolenia, podnoszenie świadomości, informowanie, praktyki i działania, których celem jest wyposażenie uczących się w wiedzę, umiejętności, refleksyjność i rozwinięcie ich postaw tak, aby mogli praktykować i bronić demokratycznych praw i obowiązków w społeczeństwie, aktywne uczestniczyć w demokratycznym życiu, aby promować i chronić demokrację i państwo prawa" (Council of Europe 2010, s. 5-6).

Edukacja obywatelska ma potencjał kształtowania społeczeństw, dlatego też wykorzystywana jest przez władze na poziomie globalnym, regionalnym, narodowym czy lokalnym do kształtowania „odpowiednich” obywateli. W związku z tym jej cele i treści często ulegają zmianie wraz ze zmianami personalnymi $\mathrm{w}$ aparacie władzy i sposobem definiowania jej najważniejszych założeń (Levinson 2014, s. 1-2). Współcześnie w dyskursie UE (i wielu krajów członkowskich) dotyczącym obywatelskości, głównym nurtem jest tzw. aktywne obywatelstwo (active citizenship) (Komisja Europejska 2015), definiowane jako:

Uczestnictwo w społeczeństwie, społeczności publicznej i / lub życiu politycznym, charakteryzujące się wzajemnym szacunkiem, niestosowaniem przemocy, zgodnie z prawami człowieka i demokracja. (...) Waha się od działań kulturalnych i politycznych do ochrony środowiska na poziomie lokalnym, regionalnym, krajowym, europejskim i międzynarodowym. Obejmuje nowe i mniej konwencjonalne formy aktywnego obywatelstwa, takie jak jednorazowe działania polityczne i odpowiedzialna konsumpcja, jak również bardziej tradycyjne formy: głosowanie w wyborach i członkostwo w partiach i organizacjach pozarządowych (Hoskins i in. 2006, s. 10-11).

W koncepcji tej zaangażowanie i partycypacja w życiu publicznym są wskaźnikami obywatelskości, czyli osiągnięcia wysoko rozwiniętych kompetencji obywatelskich. Wynika to z konstytuującego koncepcję aktywnego obywatelstwa założenia, że tylko jednostka działająca społecznie osiąga pełnię obywatelstwa. Dlatego też proces edukacyjny zachodzi najefektywniej, kiedy zapewnione są odpowiednie warunki społeczne, polityczne i kulturowe do uczestnictwa (Gierszewski 2017, s. 75)

Takie podejście jest rozwijane między innymi przez Brynon Hoskins (2006) w zaproponowanym modelu edukacji obywatelskiej (Rysunek 1). Wynika z niego, że końcowym rezultatem edukacji obywatelskiej jest właś- 
nie uczestnictwo, a kompetencje (wiedza, umiejętności i postawy) stanowią tylko element pomocniczy w stosunku do podejmowanych działań. Efektem końcowym, warunkowanym czynnikami indywidualnymi, społeczno-rodzinnymi, edukacyjnymi i środowiskowymi, jest aktywność publiczna.

\section{Rys. 1 Proces edukacji obywatelskiej}

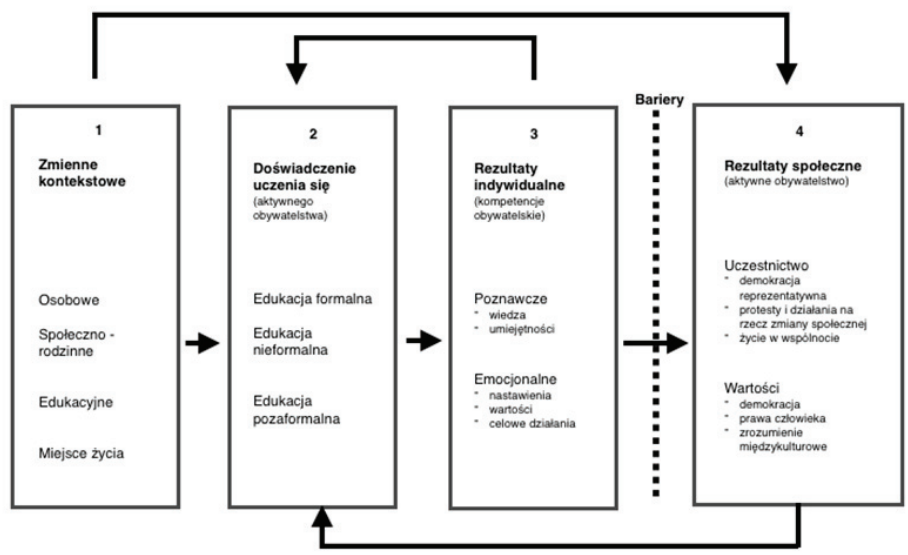

Źródło: Hoskins B. (2006), Draft Framework for Indicators on Active Citizenship, Konferencja: Working towards Indicators on Active Citizenship, Ispra, s. 9 .

Z naszej perspektywy szczególnie interesujące są dwa ostatnie elementy tego procesu: nabywanie indywidualnych kompetencji, które jest tylko etapem pośredniczącym w drodze do pełnego obywatelstwa i wykorzystywanie ich przez działanie. Nawet jeśli jednostka posiada pewne kompetencje, to występujące bariery (np. atmosfera polityczna, brak zasobów w rodzaju czasu i pieniędzy, brak wsparcia) mogą przeszkodzić jej w przejściu do ostatniego etapu rozwijania kompetencji, a w konsekwencji uniemożliwić jej stanie się pełnoprawnym obywatelem (tamże, s. 9).

Jedną z możliwości budowania takich warunków jest koncepcja współzarządzania (local governance). Polega ona na włączaniu obywateli oraz instytucji III sektora w procesy decyzyjne, prowadzone na różnych poziomach w zróżnicowanych obszarach i wymagające różnych form zaangażowania, tj.: konsultacje społeczne, komisja dialogu społecznego, budżet partycypacyjny, fundusze sołeckie i inicjatywy lokalne (Kożuch 2004, s. 16-17). Współzarzą- 
dzanie pozwala mieszkańcom rozwijać własną podmiotowość, budować poczucie przynależności i tożsamości lokalnej oraz zwiększa poziom zaangażowania (Gierszewski 2017, s. 26-27).

Aktywne obywatelstwo jest podejściem bardzo silnie opartym także na idei wspólnotowości, czyli dążeniu do budowania, a następnie wspierania spójności społeczności. Lokalny charakter tej edukacji wykorzystuje właśnie te dążenia jednostek, kształtując ich poczucie odpowiedzialności za to, co najbliższe. To właśnie poziom lokalny jest tym, na który mieszkańcy mają bezpośredni wpływ, dlatego też działania lokalne są dla nich najbardziej dostępne i najbliższe ich codziennym praktykom społecznym. O znaczeniu wspólnotowości i lokalności w edukacji dorosłych (uczące się społeczności) pisze także Ewa Kurantowicz (2007). Według niej społeczność lokalna tworzy ramy uczenia się, zachodzącego we wspólnotach zogniskowanych wokół wspólnych problemów, wyzwań lub interesów, włączających jednostki do lokalnych tożsamości zbiorowych. Proces ten odbywa się w kontekście lokalnych polityk kreowanych przez władze w celu zarządzania społecznościami.

$\mathrm{Z}$ nurtu uczenia się w społeczności wyłoniło się podejście uczenia się przez zaangażowanie (service learning) (Eyler, Giles 1999). Jest to rodzaj uczenia się poprzez doświadczenie w oparciu o działanie w bezpośrednim otoczeniu jednostek, a jednocześnie osadzone w dyskursie akademickim. Przykładem takiego sposobu uczenia się, są różnego rodzaju projekty lokalne, w których uczestnicy diagnozując lokalne zasoby, identyfikują potrzeby i problemy wspólnoty, tworzą sposoby ich rozwiązania i refleksyjnie uczestniczą w każdym etapie realizacji projektu, przez co nabywają i rozwijają szereg kompetencji obywatelskich (Gierszewski 2017, s. 114).

Koncepcja uczenia się w społecznościach jest jedną z trzech tradycji andragogicznych - lokalnej edukacji dorosłych (Johnson,2003, s. 16-17). Zgodnie z tym podejściem edukacja jest łącznikiem miedzy tym, co prywatne, a tym, co publiczne w danej społeczności i najczęściej jest wynikiem zainteresowań oraz potrzeb mieszkańców danych środowisk lokalnych, wspieranych przez lokalne (regionalne, miejskie, gminne, dzielnicowe) władze. Najchętniej wybieranym nurtem przez rządzących jest właśnie edukacja w społeczności lokalnej. W porównaniu do tradycji liberalnej, nastawionej na indywidualne efekty i rozwój osobisty, ta forma edukacji sprzyja budowaniu wspólnot i wspieraniu władz w rozwiązywaniu problemów i zaspokajaniu potrzeb społecznych. $Z$ drugiej strony, w odróżnieniu od nurtu radykalnego, według którego uczenie się ma na celu demaskowanie władzy i jej wpływów, rozpoznawanie ideologii, obronę przed wpływami kapitalizmu i biurokracji, czy wreszcie pełne praktykowanie demokracji (m.in. poprzez organizowa- 
nie protestów, strajków, zgłaszanie petycji itp.) (Brookfield 2005, s. 17-25), edukacja społecznościowa może być do pewnego stopnia modelowana i kontrolowana przez rządzących.

W dyskursie andragogicznym (Johnson 2003; Kurantowicz 2007; Gierszewski 2017) jak i politykach władz (Parlament Europejski 2006; Hoskins i in. 2006; Komisja Europejska, 2015) największą popularnością cieszą się przedstawione powyżej nurty i koncepcje edukacji obywatelskiej dorosłych, które koncentrują się na aktywnym obywatelstwie. Istnieją jednak autorzy, którzy odnoszą się do tego podejścia krytycznie (Kearns 1995, s. 155-175; Davies 2012, s. 3-19; Bee, Guerrina 2014, s. 29-55), uważając, że jest ono osadzone w neoliberalnym dyskursie, któremu obywatele muszą się podporządkować i według którego aktywne obywatelstwo jest jedynym możliwym sposobem realizacji obywatelskości. Jednostki konstruujące i praktykujące obywatelskość w inny sposób nie są uważane za pełnoprawnych obywateli (Kymlicka 1995, s. 146-155). Konstruktywistyczne podejście do obywatelskości podważa taki sposób definiowania tego, kim jest obywatelem. Autorzy tego nurtu kładą nacisk na to, z jakich elementów jednostki konstruują swoja tożsamość obywatelską i jak definiują swoje zadania w tej roli (Jochum, Pratten, Wilding 2005, s. 27). Z tej perspektywy wyprowadzanie psa sąsiada może być zachowaniem obywatelskim, jeśli tylko jednostka definiuje je w ten sposób.

\section{Rys. 2.Kontinuum aktywnego obywatela}

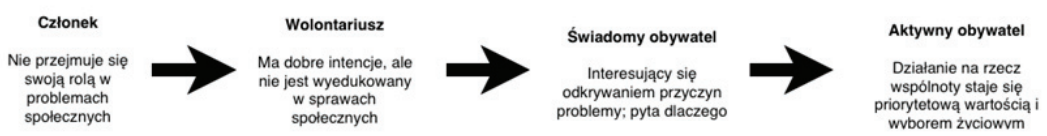

Warto w tym kontekście zwrócić również uwagę na procesualność lub sekwencyjność stawania się obywatelem. Ten procesualny charakter obrazuje kontinuum aktywnego obywatela, gdzie wyszczególnione zostały etapy, przez jakie przechodzą członkowie wspólnoty, aby móc stać się aktywnymi obywatelami (Break Away 2014, s. 2). Model ten można odczytywać w perspektywie rozwoju kolejnych kompetencji, gdzie aktywny obywatel 
jest typem idealnym. Można też traktować go jako zbiór różnorodnych modeli obywatelstwa, z których jednostka może wybierać.

\section{Obywatelska edukacja dorosłych w dokumentach władz Warszawy}

W ramach prowadzonego przez nas projektu badawczego, dotyczącego edukacji obywatelskiej w wybranych miastach Polski, przeprowadziłyśmy wstępną analizę tego zjawiska w Warszawie. Wybrałyśmy to miasto, gdyż dysponuje ono największym budżetem na wspieranie działalności edukacyjnej, a ponadto przoduje we wprowadzaniu innowacji społecznych. Na samym początku wstępnej analizy dokumentów miejskich związanych z edukacją obywatelską przejrzałyśmy strategie, programy i projekty z okresu 2008-2017 (okres wprowadzania ostatniej strategii rozwoju miasta). Z tej puli dokumentów wybrałyśmy te, które w swojej treści odwoływały się bezpośrednio do edukacji obywatelskiej lub też do podnoszenia kompetencji obywatelskich*. Były to: Strategia rozwoju m. st. Warszawy do 2020 roku; Społeczna strategia m. st. Warszawy na 2009-2020; programy: Rozwój dialogu i komunikacji społecznej; Program rozwoju wspótpracy m. st. Warszawy i organizacji pozarzadowych do roku 2020; Program rozwoju edukacji w Warszawie w latach 2013-2020; Warszawski Program Edukacji Kulturalnej 2015-2020; Program Wzmacniania Wspólnoty Lokalnej 2015-2020. Analizowałyśmy również oficjalne zapisy odnoszące się do warszawskiego budżetu partycypacyjnego, domów sąsiedzkich i MAL-i (zarządzenia prezydenta m.st. Warszawy, uchwały Rady Warszawy, regulaminy) oraz raporty ewaluacyjne. Do analizy wybrałyśmy dwa konkretne działania (budżet partycypacyjny oraz domy sąsiedzkie i MAL-e) dlatego, że są one najbardziej znaczącymi elementami miejskiej strategii oraz podlegają bezpośrednio władzom miejskim, przeznaczającym na ich utrzymanie i rozwój kadry znaczące środki.

Z syntezy analizowanych strategii i programów wynika, że głównymi celami edukacji obywatelskiej osób dorosłych jest: podnoszenie kompetencji związanych z szeroko rozumianą aktywnością obywatelską; budowanie postawy otwartości na zróżnicowanie społeczne; wzmacnianie poczucia solidarności i współodpowiedzialności za wspólnotę lokalną; rozwijanie kompetencji związanych z prowadzeniem dialogu i konsultacji społecz-

\footnotetext{
* Na potrzeby badania stworzyłyśmy katalog kompetencji obywatelskich w oparciu o: Hoskins i in., 2006, s. 9; Jochum, Pratten, Wilding, 2005, s. 27.
} 
nych; zwiększanie wiedzy dotyczącej funkcjonowania samorządu lokalnego i wzmacnianie postawy samorządnościowej. Jak można zauważyć, powyższe zapisy koncentrują się przede wszystkim na budowaniu wspólnoty i uczeniu się w jej ramach, co sytuuje ją w tradycji uczenia się w społecznościach (Johnson 2003, s. 16-17). Dotyczą one jednak raczej efektów związanych ze zmianą społeczną, a nie celów stricte edukacyjnych, których podmiotem jest uczący się. Możliwe, że przyczyną tego jest fakt, że edukację obywatelską dorosłych realizuje Centrum Komunikacji Społecznej, a nie Biuro Edukacji, które zajmuje się tym zagadnieniem w kontekście dzieci.

Nastawienie na lokalność widać również w konkretnych narzędziach edukacyjnych wdrażanych przez miasto - budżecie partycypacyjnym i domach sąsiedzkich. Budżet partycypacyjny to „proces decyzyjny, w ramach którego mieszkańcy współtworzą budżet danego miasta, tym samym współdecydując o dystrybucji określonej puli środków publicznych" (Kłębowski 2013 , s. 8). Jest on więc elementem współzarządzania. Poza modelowaniem relacji obywatel - władza (Baiocchi, Ganuza 2014 s. 19), może mieć on również silne edukacyjne oddziaływanie. Dzięki temu rozwiązaniu mieszkańcy mogą pogłębić swoją wiedzę w kwestii konstruowania i wydatkowania lokalnych środków, źródeł wpływów finansowych oraz zobowiązań budżetowych. Pozwala ono także zdobyć wiedzę o funkcjonowaniu samorządu lokalnego, powiązaniach $z$ innymi agendami władzy, prawach mieszkańców oraz kontroli władzy (Kłębowski 2013, s. 5). Innym aspektem edukacyjnym jest jego deliberacyjny charakter, obejmujący m.in. debaty i konsultacje społeczne (Koch Podkański, 2015, s. 25). Przygotowywanie projektów w ramach budżetu partycypacyjnego może wpływać na wzrost wiedzy o potrzebach społeczności lokalnej i umiejętności diagnozowania jej problemów, zwiększenie spójności społecznej oraz może stanowić podstawę do inkluzji grup wykluczonych poprzez wysłuchiwanie ich głosu i włączanie we współdecydowanie o kierunkach rozwoju dzielnicy.

$\mathrm{Z}$ naszej analizy warszawskiego budżetu partycypacyjnego wynika, że jego edukacyjny charakter nie jest wystarczająco wykorzystywany. W działania związane $z$ pisaniem i omawianiem projektów zgłoszonych do głosowania włączają się głównie ich autorzy i ewentualnie urzędnicy miejscy (uwarunkowane jest to prawnie). $Z$ kolei napisanie i wypromowanie projektów wymaga pewnych kompetencji i sieci kontaktów, których brakuje wielu osobom, więc nawet nie próbują włączyć się w ten typ konsultacji. Warto również zwrócić uwagę na to, że mimo iż budżet ma pełnić przede wszystkim rolę edukacyjną, to jego wprowadzenie nie zostało poprzedzone diagnozą tego, co właściwie stanowi dobrą praktykę realizacji procesów edukacyjnych. 
Budżet partycypacyjny pełni funkcje edukacyjne przez współzarządzanie (local governance), natomiast domy sąsiedzkie związane są z koncepcją uczenia się poprzez zaangażowanie (service learning). Finansowane są bezpośrednio przez władze których głównym celem jest wspieranie procesów społecznej zmiany poprzez udostępnienie mieszkańcom zasobów potrzebnych do jej przeprowadzenia (Sitek-Wróblewska i in. 2011, s. 15). Należą one do większej sieci Miejsc Aktywności Lokalnych (tzw. MAL-i) (Centrum Komunikacji Społecznej 2015, s. 18), czyli przestrzeni nieodpłatnie udostępnianych mieszkańcom na działania społeczne. Obywatele poprzez realizowanie działań na rzecz najbliższego środowiska (np. warsztaty, spotkania, pikniki, koncerty) mogą nabywać kompetencje związane z diagnozowaniem i organizowaniem społeczności, budowaniem poczucia współodpowiedzialności oraz wzmacnianiem relacji międzyludzkich (Sitek-Wróblewska i in. 2011, s. 17). Domy sąsiedzkie przez swoją ogólnodostępność mają też potencjał inkluzyjny, gdyż zatrudniają animatorów, których zadaniem jest wspieranie osób z mniejszymi kompetencjami.

Jak wynika z naszej analizy domów sąsiedzkich, opisany wyżej potencjał nie jest do końca wykorzystywany. Głównie to pracujący w nich animatorzy proponują i organizują różnego typu zajęcia. Podobnie jak w przypadku budżetu partycypacyjnego, działania edukacyjne skierowane są w praktyce do aktywnych mieszkańców, którzy potrzebują przestrzeni na swoje działania, a mieszkańcy z mniejszymi kompetencjami są jedynie biernymi odbiorcami (o ile w ogóle pojawią się w takim miejscu, które w swym ukrytym programie wydaje się być przeznaczone dla klasy średniej).

\section{Warszawska koncepcja edukacji obywatelskiej dorosłych - mocne i słabe strony}

Jak wynika z powyższej wstępnej analizy strategii i bezpośrednich rozwiązań edukacji dorosłych, warszawskie działania, mające na celu podniesienie kompetencji obywatelskich, zakorzenione są w nurcie aktywnego obywatelstwa. W nurcie tym najważniejsza jest partycypacja jednostek na rzecz i we wspólnocie lokalnej (domy sąsiedzkie, budżet partycypacyjny), która jest oznaką osiągnięcia pełni obywatelskości. Podążając za głównymi założeniami tego nurtu, warszawscy decydenci kładą nacisk na tworzenie sprzyjających warunków do uczestnictwa (np. komisja dialogu społecznego; współdecydowanie o budżecie miasta; tworzenie miejsc, których obywatele mogą działać na rzecz innych). 
Naszym zdaniem koncepcja aktywnego obywatelstwa oparta na uczeniu się w społecznościach lokalnych nie jest do końca efektywna. Oparta jest na założeniu, że społeczność jest bliską jednostce przestrzenią materialną i społeczną, z którą jednostka może się utożsamiać i czuć więź. Taka społeczność, czyli „społeczność, która żyje na niewielkiej przestrzeni, a jej członkowie są skupieni wokół aprobowanych wartości, celów, interesów" (Theiss, Skrzypczak 2006, s. 34), tworzy się w sposób naturalny głównie na terenach, gdzie tkanka społeczna jest dość stabilna. W Warszawie, wyniszczonej przez II wojną światową, w której odczuwalny jest stały przepływ ludności, mamy do czynienia raczej ze społecznością w budowie. Dostrzegając ten fakt, decydenci miejscy starają się facylitować ten proces (Rada m. st. Warszawy 2008; Centrum... 2015), lecz jednocześnie proponują proces edukacyjny, który wymaga ukształtowanych już wspólnot.

Z przeprowadzonej analizy wynika również, że miejscy decydenci dość powierzchownie rozumieją edukację obywatelską dorosłych, ponieważ w miejskich dokumentach nie pojawia się edukacja rozumiana jako proces edukacyjny - $\mathrm{z}$ zoperacjonalizowanymi celami, konkretnymi treściami bądź sugerowanymi metodami i narzędziami*. Cele formułowane przez rządzących są celami społecznymi, które uda osiągnąć się, jeśli obywatele będą mieli odpowiednie kompetencje (np. Poprawa dialogu społecznego i obywatelskiego, Rada m. st. Warszawy 2008, s. 69). Treści miejskiej edukacji obywatelskiej dorosłych dotyczą głównie poziomu lokalnego, sposobów współpracy z władzami samorządowymi oraz pokojowego współistnienia ze współobywatelami. Są to kompetencje, które można odnaleźć w omawianej przez nas powyżej koncepcji aktywnego obywatela (por. Hoskin i in. 2006 s. 9). Brak tutaj jednak treści związanych z krytycznym myśleniem, umiejętnościami kwestionowania i podważania decyzji władz czy kompetencjami związanymi z prowadzeniem protestów. Biorąc pod uwagę źródła finansowania tej edukacji, wydaje się oczywiste, że władza sponsoruje jedynie kształtowanie konformistycznych kompetencji.

Najbardziej niepokojący w edukacyjnych propozycjach warszawskich władz jest fakt, że ich odbiorcami są przede wszystkim osoby posiadające już do pewnego stopnia rozwinięte kompetencje obywatelskie. Głównie są to liderzy społeczności lokalnych, lokalni urzędnicy, członkowie NGO, którzy dzięki stworzonym przez rządzących możliwościom mogą włączyć się

* W dokumentach tworzonych przez Biuro Edukacji m. st. Warszawy (Rada m. st. Warszawy, 2013), dotyczących edukacji obywatelskiej dzieci i młodzieży (ale nie dorosłych), proces dydaktyczny jest zoperacjonalizowany. 
we współzarządzanie miastem. Edukacja ta głównie ma charakter „doskonalenia zawodowego" przyszłych i obecnych liderów lokalnych. W zaproponowanych formach działań, opisanych w oficjalnych dokumentach, brakuje jednak strategii docierania do osób o niskich kompetencjach obywatelskich, które powinny być priorytetowymi odbiorcami edukacji obywatelskiej.

Z naszej wstępnej analizy wynika zatem, że w Warszawie nie ma spójnej polityki w zakresie obywatelskiej edukacji dorosłych. Jest ona rozproszona w różnych strategiach i programach, które dotyczą pewnych jej aspektów. Co więcej, władze miejskie kładą mały nacisk na sam proces edukacyjny, ograniczając rolę edukacji obywatelskiej tylko do narzędzia używanego do wprowadzania określonych zmian społecznych poprzez animację społeczną, wzmacnianie lokalności i spójności społecznej. Nie jest ona jednak narzędziem inkluzji, gdyż jej odbiorcami są głownie aktywni mieszkańcy, a nie grupy defaworyzowane.

\section{Bibliografia}

Bee, C., Guerrina, R. (2014), Participation, dialogue, and civic engagement: Understanding the role of organized civil society in promoting active citizenship in the European Union, „Journal of Civil Society”, s. 29-55.

Baiocchi G., Ganuza E. (2014), Participatory budgeting as if emancipation mattered, „Politics \&Society”, 42(1), s. 29-50.

Boryczko M. (2014), Od analizy potoczności do organizowania działania kolektywnego - o teoretycznych założeniach krytycznej animacji społecznej, [w:] Boryczko M i.in. (red.), Aktywna biografia w przestrzeni społecznej, Eko-Inicjatywa, Kwidzyn s. 49-62.

Break A. (2014), Active Citizen Continuum, Kansas.

Brookfield S. (2005), The Power of Critical Theory for Adult Learning and Teaching, Two Penn Plaza, New York.

Centrum Komunikacji Społecznej (2015), Program Wzmacniania Wspólnoty Lokalnej 2015-2020, Warszawa.

Council of Europe (2010), Recommendation CM/Rec (2010) 7 of the Committee of Ministers to Member States on the Council of Europe Charter on Education for Democratic Citizenship and Human Rights Education, Brussel.

Davies J. (2012), Active citizenship: Navigating the conservative heartlands of the New Labour project, „Policy \& Politics”, 40(1), s. 3-19.

Eyler J., Giles D. E. (1999), Where's the learning in service-learning?, Ossey-Bass Publishers, San Francisco. 
Gierszewski D. (2017), Edukacja obywatelska w przestrzeni lokalnej, Wydawnictwo Uniwersytetu Jagielońskiego, Kraków.

Hoskins B. (2006), Draft Framework for Indicators on Active Citizenship, Konferencja: Working towards Indicators on Active Citizenship, Ispra, Wrzenień 2006.

Hoskins B., i in. (2006), Measuring Active Citizenship in Europe, European Commission Institute for the Protection and Security of the Citizen, Ispra.

Jochum V., Pratten B., Wilding K. (2005), Civil renewal and active citizenship: A guide to the debate, NCVO, London.

Johnson R. (2003), Adult Learning and Citizenship: Clearing the Ground, [w:] Coare P., Johtson R. (red), Adult learning, citizenship and community learning, NIACE, Oxford.

Kearns A. (1995), Active citizenship and local governance: Political and geographical dimensions, „Political Geography”, 14(2), s. 155-175.

Kłębowski W. (2013), Budżet partycypacyjny. Krótka instrukcja obsługi, Instytut Obywatelski, Warszawa.

Koch A., Potkański T. (red.) (2015), Gra o budżet. Narzędzie zwiększające partycypację w zarządzaniu miastem, Centrum Rozwiązań Systemowych, Wrocław.

Kożuch B. (2004), Zarządzanie publiczne. W teorii i praktyce polskich organizacji, Placet, Warszawa.

Kurantowicz E. (2007), O uczących się społecznościach. Wybrane praktyki edukacyjne ludzi dorosłych, Wydawnictwo Naukowe Dolnośląskiej Szkoły Wyższej Edukacji TWP, Wrocław.

Komisja Europejska (2015), Deklaracja w sprawie promowania, poprzez edukacje, obywatelstwa i wspólnych wartości, jakimi sq wolność, tolerancja i niedyskryminacja, Paryż.

Kymlicka, W. (1995), Multicultural Citizenship, Clarendon Press, Oxford.

Levinson M. (2014), Citizenship and Civic Education, [w:] Phillips D.C. (red.), Encyclopedia of Educational Theory and Philosophy, Sage, Thousand Oaks.

Parlament Europejski (2006), Zalecenie Parlamentu Europejskiego z dnia 18 grudnia 2006 r. w sprawie kompetencji kluczowych $w$ procesie uczenia się przez całe życie, Bruksela.

Rada m.st. Warszawy (2008), Społeczna strategia m.st Warszawy na 2009-2020, Warszawa.

Rada m.st. Warszawy (2013), Program rozwoju edukacji w Warszawie w latach 2013-2020, Warszawa.

Sitek-Wróblewska M. i in. (2011), Model Domu Sąsiedzkiego, Gdańska Fundacja Innowacji Społecznej, Gdańsk.

Theiss W., Skrzypczak B. (2006), Edukacja i animacja społeczna w środowisku lokalnym, Centrum Wspierania Aktywności Lokalnej CAL, Warszawa. 